\title{
Chromosomal investigations in patients with mental retardation and/or congenital malformations
}

\author{
C.B. Santos, R.T. Boy, J.M. Santos, M.P.S. Silva and M.M.G. Pimentel
}

\begin{abstract}
We investigated the chromosomal constitution of patients with mental retardation and/or congenital malformations in order to determine genetic causes for such disturbances. The GTG and CBG banding patterns were studied using phytohemagglutinin M-stimulated lymphocytes cultured from peripheral blood. Among 98 individuals with mental retardation and/or congenital malformations who were analyzed there were 12 cases of Down's syndrome, two of Edward's syndrome, one of Patau's syndrome, five of Turner's syndrome, two of Klinefelter's syndrome, one of "cri-du-chat" syndrome, one case of a balanced translocation between chromosomes 13 and 14, one case of a derivative chromosome and one of a marker chromosome. We found abnormal chromosomes in $26 \%$ of the patients, $82 \%$ of which were numerical abnormalities, with the remaining $18 \%$ being structural variants. We conclude that patients with mental retardation and/or congenital malformations should be routinely karyotyped.
\end{abstract}

\section{INTRODUCTION}

Chromosomal abnormalities affect at least $7.5 \%$ of all conceptions. Most of these abnormalities are spontaneously aborted and the frequency in live births is $0.6 \%$ (Connor and Ferguson-Smith, 1991). Three percent to four percent of all births are associated with a major congenital malformation, mental retardation, or genetic disorder, a rate that doubles by seven to eight years of age, with later-appearing or later-diagnosed genetic disorders (Milunsky et al., 1992). A great number of chromosomal disorders are associated with mental retardation. According to the World Health Organization, the prevalence rate of mental retardation in industrialized countries comes close to $3 \%$ (Roeleveld et al., 1997). In developing countries, the prevalence of mental retardation is higher. In Brazil it has been estimated as 6.7 per 1000 live births (Félix et al., 1998).

In most Latin American countries, chromosomal disorders have not received much attention from state and federal governments, partly because the main health problems responsible for childhood morbidity and mortality are of socioeconomic and environmental origin. Chromosomal disorders are included among the most important causes of childhood mortality in Latin American countries (OPS, 1984); nevertheless, few public health services perform cytogenetic studies.

\section{MATERIAL AND METHODS}

We examined the frequency of chromosomal disorders in Rio de Janeiro (Brazil) over a two-year period. The patients were investigated by a public health genetic service and were initially screened at the Hospital Universitário Pedro Ernesto. The subjects consisted of patients with mental retardation and congenital malformations who were identified by a clinical geneticist as possibly carrying a chromosomal abnormality. Ninety-eight individuals were analyzed ( 45 males, 53 females; sex ratio $=0.85$ ). The subjects ranged in age from two days old to 36 years old $(\overline{\mathrm{x}}=11.5 \pm 10.6$ years). There was no case of consanguinity. Most of the patients were from the pediatrics department, although a few others were from the neurology department, the main emergency room and adjacent hospitals. The analyzed individuals included 98 patients with congenital malformations, $85 \%$ of whom had both mental retardation and congenital malformations, while $15 \%$ had only congenital malformations. Blood samples were collected from all patients into heparinized-test tubes. Cytogenetic analyses were performed on cultured peripheral blood lymphocytes stimulated with phytohemagglutinin M, using standard techniques (Moorhead et al., 1960). The karyotype was determined in all patients by GTG banding (Caspersson et al., 1970) and, when necessary, CBG banding (Salamanca and Armendares, 1974). At least 30 cells were routinely analyzed, but in cases of mosaicism this number was increased to approximately 100 metaphases. The best metaphases were photographed to determine the karyotypes. In all cases in which translocations or unusual karyotypes were found, blood samples were collected from both parents and their chromosomes were studied.

\section{RESULTS}

Abnormal chromosomes were found in $26 \%$ of the patients, $82 \%$ of which were numerical abnormalities with

Serviço de Genética Humana, Departamento de Biologia Celular e Genética, Instituto de Biologia Roberto Alcântara Gomes, Universidade do Estado do Rio de Janeiro, Rua São Francisco Xavier, 524, Pavilhão Haroldo Lisboa da Cunha, $2^{\circ}$ andar, sala 205, Maracanã, 20550-013 Rio de Janeiro, RJ, Brasil. Send correspondence to M.M.G.P. E-mail: cbs@alternex.com.br 
the remaining (18\%) being structural variants (Table I). The frequency of abnormal chromosomes in the individuals with congenital malformations and/or mental retardation was approximately $29 \%$. Cytogenetic studies of the parents of individuals with translocations or of the other cases with an unusual karyotype showed normal chromosomes, except for one case of Down's syndrome (DS) with a translocation between chromosomes 14 and 21, where the patient's mother had a derived chromosome in some of her cells.

\section{DISCUSSION}

The results obtained provide the basis of a regional cytogenetic data library designed to help in the genetic counseling of families who require this service. With this approach, a definitive diagnosis for a chromosomal disorder was recorded in $28.6 \%$ of the patients with mental retardation and/or congenital malformations. The frequency of chromosomal anomalies was higher than that found by Fryns et al. (1986) (15.03\%), Dereymaeker et al. (1988) (13.3\%) and Fryns et al. (1990) (17.6\%), but lower than that observed in two other studies (Gustavson et al., 1977; Laxova et al., 1977): 32 and $32.2 \%$, respectively. The differences in the frequencies of chromosomal abnormalities among these studies are probably due to variations in the criteria for inclusion of patients and the cytogenetic methodology applied.

\section{Abnormalities involving the sex chromosomes}

Among Turner's syndrome patients, the most frequent sexual abnormality in our findings, somatic mosaicism $(45, \mathrm{X} / 46, \mathrm{XX})$ was more common (four of five) than the classic karyotype (45,X). Klinefelter's syndrome was the second most frequent sexual abnormality and showed the classic, well-defined phenotype. Small testes were observed in both patients, whereas gynecomastia, which appears in only 1/3 of Klinefelter patients (Jorde et al., 1996), occurred in one of the two patients.

There were two cases of somatic mosaicism with three cell lines involving the sex chromosomes. In the first case $(45, \mathrm{X} / 46, \mathrm{XX} / 47, \mathrm{XXX})$, the phenotype included short stature and primary amenorrhea resulting from the $45, X$ cell line. The other abnormal cell line $(47, \mathrm{XXX})$ had no well-defined expression because of $X$ chromosome inactivation. In the second case $(45, \mathrm{X} / 46, \mathrm{XY} / 47, \mathrm{XYY})$, the clinical findings were genital ambiguity, resulting from overlap of the phenotypic characteristics produced by the $45, X$ and 46,XY cell lines, and behavioral problems, such as offensiveness and psycho-social difficulties.

Even though fragile $\mathrm{X}$ syndrome is the most common form of inherited mental retardation and the second most frequent cause of mental retardation after DS, the diagnosis of this disorder based on cytogenetic detection of the fragile site Xq27.3 is laborious, since the fragile site has to be induced by specific chemical treatments, which could provoke misdiagnosis. In addition to the difficulties of identifying fragile $\mathrm{X}$ expression in females, there is considerable potential for false negatives due to males that are mosaic for the full mutation, and false positives due to closely linked fragile sites (FRAXE and FRAXF). Moreover, it does not identify the clinically normal carriers, limiting the cytogenetic value in genetic counseling (Pimentel, 1999). That is the reason why we did not include patients referred for fragile $\mathrm{X}$ analysis in this cytogenetic study.

Table I - Cytogenetic results for 98 mental retardation patients from the Hospital Universitário Pedro Ernesto and other adjacent hospitals, showing the frequency of abnormalities and the numbers of each sex involved.

\begin{tabular}{|c|c|c|c|c|}
\hline $\begin{array}{l}\text { Chromosomal } \\
\text { abnormality }\end{array}$ & Karyotype & $\begin{array}{c}\text { Number of } \\
\text { cases }\end{array}$ & $\begin{array}{c}\text { Percentage } \\
(\%)\end{array}$ & Sex \\
\hline \multirow[t]{4}{*}{ Down's syndrome } & $47, \mathrm{XX},+21$ or $47, \mathrm{XY},+21$ & 9 & $12.2 \%$ & $1 \mathrm{M} / 11 \mathrm{~F}$ \\
\hline & $46, X X / 47, X X,+21 q-$ & 1 & & \\
\hline & $46, X X,-14,+t(14 q 21 q)$ & 1 & & \\
\hline & $46, X X,-21,+t(21 q 21 q)$ & 1 & & \\
\hline \multirow[t]{2}{*}{ Edward's syndrome } & $47, \mathrm{XX},+18$ & 1 & $2 \%$ & $1 \mathrm{M} / 1 \mathrm{~F}$ \\
\hline & $46, X X / 47, X X,+18$ & 1 & & \\
\hline Patau's syndrome & $46, X X / 47, X X,+13$ & 1 & $1 \%$ & $1 \mathrm{~F}$ \\
\hline \multirow{2}{*}{ Turner's syndrome } & $45, \mathrm{X}$ & 1 & $5.1 \%$ & $5 \mathrm{~F}$ \\
\hline & $45, X / 46, X X$ & 4 & & \\
\hline Klinefelter's syndrome & $47, X X Y$ & 2 & $2 \%$ & $2 \mathrm{M}$ \\
\hline "Cri-du-chat" syndrome & $46, X Y, 5 p-$ & 1 & $1 \%$ & $1 \mathrm{M}$ \\
\hline Balanced translocation & $45, \mathrm{XY},-13,-14,+\mathrm{t}(13 ; 14)$ & 1 & $1 \%$ & $1 \mathrm{M}$ \\
\hline Somatic mosaicism with 3 & $45, \mathrm{X} / 46, \mathrm{XX} / 47, \mathrm{XXX}$ & 1 & $2 \%$ & $1 \mathrm{M} / 1 \mathrm{~F}$ \\
\hline cell lines & 45,X/46,XY/47,XYY & 1 & & \\
\hline Derivative chromosome & 46,XX/47,XX,+der(D) & 1 & $1 \%$ & $1 \mathrm{~F}$ \\
\hline Marker chromosome & 46,XY/47,XY,+mar (21) & 1 & $1 \%$ & $1 \mathrm{M}$ \\
\hline Normal & $46, X X$ or $46, X Y$ & 57 & $58.2 \%$ & $32 \mathrm{M} / 25 \mathrm{~F}$ \\
\hline $\begin{array}{l}\text { Cases with unsatisfactory } \\
\text { cell growth }\end{array}$ & - & 13 & $13.3 \%$ & $5 \mathrm{M} / 7 \mathrm{~F}$ \\
\hline
\end{tabular}

$\mathrm{M}=$ male; $\mathrm{F}=$ female 


\section{Autosomal trisomies}

DS, besides being the most common anomaly in the group of trisomies, was also the most frequent $(11 \%)$ of all the chromosomal abnormalities. Eight of the 12 DS cases were children less than one year old, indicating that the diagnosis was precocious in most cases. The strong sex bias for DS (11 of 12 were female) observed in this cohort could be a consequence of the small sample size and are not suggestive of a higher incidence of females than males with DS in our region. Astete et al. (1991) described a cytogenetic study with a larger Down's sample size showing an almost equal sex ratio (56.4\% of male gender) among the individuals with the syndrome.

In agreement with previous reports (Thompson et al., 1993), there was considerable karyotype variability in individuals with DS, including cases of free trisomy (nine cases) and partial free trisomy (one case) of chromosome 21, as well as Robertsonian translocations between chromosomes 14 and 21 (one case) and between the two chromosomes 21 (one case). These observations emphasize the importance of cytogenetic confirmation in cases of DS. In addition to indicating the risks of recurrence of the syndrome, karyotyping can also be useful in the clinical follow-up of some disorders associated with DS. Certain diseases, such as duodenal stenosis, Alzheimer's disease and acute leukemia, seem to be more common in DS patients than in the general population (Fong and Brodeur, 1987). In the case of acute leukemia, for example, the incidence can be 14-30 times more frequent in DS patients (Iselius et al., 1990). By identifying each karyotype associated with DS, it is possible to inform the patient's family about the susceptibility to acute leukemia, duodenal stenosis and Alzheimer's disease and help them notify the associated symptoms. Treatment can then be introduced early, thereby increasing the patient's life expectancy.

Of the two individuals diagnosed with Edward's syndrome, one had the classic karyotype $(47, \mathrm{XX},+18)$ and the other showed somatic mosaicism $(46, \mathrm{XX} / 47, \mathrm{XX},+18)$. According to Giaccardi et al. (1991), most fetuses with trisomy 18 are spontaneously aborted. However, when the pregnancy is brought to term, the post-natal lifetime is limited to 1-2 months in $80 \%$ of the cases, except when there is somatic mosaicism. In the latter situation, the individual lives longer because of the presence of normal cell lines, which attenuate the syndromic features. Our findings confirmed that a carrier of somatic mosaicism had a significantly longer lifetime than a carrier of the classic karyotype. The first patient had been clinically accompanied until four years old, while the latter died in the first month of life.

Only one individual was identified as having Patau's syndrome. This disease is well known for its low life expectancy and the well-defined features that allow an early diagnosis in the first days of life, except in cases of mosaicism. Taylor (1968) reported the mean lifetime of children with trisomy 13 to be 89.2 days, although there may be exceptions (Zool et al., 1993). Somatic mosaicism increased the lifetime of our patient and masked the clearcut expression of the syndrome because of the presence of a normal cell line. The latter cells delayed diagnosis, until when the girl was already five months old.

\section{Somatic mosaicism}

According to Fernandez et al. (1996), the detection of mosaicism depends mainly on four factors: a) the type and number of tissues analyzed, the number of cells studied (Hook, 1977), the sensitivity of the techniques applied and the possible selection that may result in the disappearance of cell lines (Procter et al., 1984).

In addition to the cases of somatic mosaicism related to the syndromes described above, four patients had clinical indications of possible mosaicism, although they were not diagnosed as having any chromosomal abnormality. These cases may represent examples of "non-detected mosaicism" since mosaicism is usually expressed in only a few tissues of the organism and may be related to cell migration during embryonic development. If gonadal tissues are involved, the frequency of affected children will depend on the proportion of affected gametes (Thompson et al., 1993). This is of great importance because genetic counseling should consider the possibility of an elevated risk of recurrence due to gonadal mosaicism in one parent. Cultures of other types of tissue ruled out the existence of gonadal mosaicism in the four patients reported here.

\section{Structural chromosomal abnormalities}

\section{Deletions}

One patient was diagnosed as carrying a deletion on chromosome 5 (5p-), characteristic of the "cri-du-chat" syndrome. The breakage occurred in the $5 \mathrm{p} 15.2$ region, as reported in the literature. Gersh et al. (1995) stated that the critical 5p15.3 region contains a gene which, when appearing as a single copy, is responsible for the cat-like cry, whereas the genes responsible for the facial features and motor delay are located in the $5 \mathrm{p} 15.2$ region. The child observed here had the clinical characteristics of the syndrome, including motor delay, microcephaly, facial dysmorphism and the cat-like cry after birth. These findings agree with the observation that the breakage occurred in the $5 \mathrm{p} 15.2$ region. The child's parents were examined to verify whether one of them carried a reciprocal translocation involving $5 \mathrm{p}$ or had mosaicism with normal and $5 \mathrm{p}$ cells. No chromosomal alterations were found in the parents, thus greatly reducing the risk of recurrence in future siblings.

Three other patients had the clinical signs of PraderWilli syndrome, but there were no alterations in their chromosome 15 . Seventy percent of individuals with this syndrome have a deletion in the q11q13 region of the chro- 
mosome 15 (Lyons, 1996), which can be detected by cytogenetic techniques. In the remaining $30 \%$, the condition results from a maternal disomy (i.e., the individual has two maternal copies and no paternal copy of 15q). This explains why in such cases it is necessary to use DNA-specific tests to detect this syndrome. The three patients in this study were counseled to seek this type of test in order to confirm the syndrome.

\section{Robertsonian translocations}

Three individuals with Robertsonian translocations were found. According to Opitz et al. (1979), Robertsonian translocations generally involve a junction between the long arms of the involved chromosomes, with loss of their short arms. Since the short arms of acrocentric chromosomes do not contain essential genetic material, their loss in balanced translocations does not affect the carrier's phenotype. Nevertheless, the carrier's offspring can inherit an extra long arm or may lack one of the acrocentric chromosomes involved in the parent's translocation and thus be affected. The patient with a translocation between chromosomes 13 and 14 showed mental retardation and some dysmorphism, suggesting that in addition to the loss of the short arms, he may have also lost some nearby regions.

\section{Marker chromosomes}

Only one case of a marker chromosome was found. The marker chromosome appeared in $25 \%$ of this individual's cells and was classified as a small acrocentric chromosome, probably a segment of chromosome 21 .

The high frequency of cases with unsatisfactory cell growth $(13 \%)$ was considered to be a consequence of the heavy medication and X-rays to which the patients were exposed.

In conclusion, although cytogenetic techniques are sometimes tedious, they are very important for the correct identification of a variety of syndromes. The information obtained by such techniques provides a basis for determining the risks of recurrence and for deciding the necessary clinical treatment and genetic counseling. However, the success of providing a clinical diagnosis with cytogenetic techniques could be improved using FISH and other complementary molecular studies. Certainly, the replacement of cytogenetic diagnosis by direct DNA diagnosis has great importance, but cytogenetic still has an important role to play in Latin American public hospitals, since molecular diagnosis is not yet a routine procedure in this region.

\section{ACKNOWLEDGMENTS}

The authors thank Dr. Ivar Pinheiro Aranha for reviewing the manuscript and for providing helpful suggestions. This work was supported by grants from the Universidade do Estado do Rio de Janeiro.

\section{RESUMO}

Neste estudo investigamos a organização cromossômica de pacientes com retardo mental e/ou malformações congênitas, visando a avaliação de causas genéticas associadas a estes distúrbios. Os padrões de bandas GTG e CBG foram estudados a partir da cultura de linfócitos de sangue periférico, estimulados por fitohemaglutinina M. Dentre os 98 indivíduos portadores de retardo mental e/ou malformações congênitas analisados, diagnosticamos as seguintes síndromes: 12 casos de Down, dois de Edwards, um de Patau, cinco de Turner, dois de Klinefelter, um de "cri-du-chat", e um caso de translocação balanceada entre os cromossomos 13 e 14, um caso de cromossomo derivado e um outro de cromossomo marcador. Encontramos anomalias cromossômicas em $26 \%$ dos pacientes, das quais $82 \%$ eram alterações numéricas e o restante (18\%) representou rearranjos estruturais. Este percentual significativo enfatiza o uso da cariotipagem de rotina em pacientes com retardo mental e/ou malformações congênitas.

\section{REFERENCES}

Astete, C., Youlton, R., Castillo, S., Be, C. and Daher, V. (1991). Clinical and cytogenetic analysis of 257 cases of Down's syndrome. Rev. Chil. Pediatr. 62: 99-102.

Caspersson, T., Zech, L. and Johansson, C. (1970). Differential banding of alkylating fluorochromes in human chromosomes. Exp. Cell Res. 60 : 315-319.

Connor, J.M. and Ferguson-Smith, M.A. (1991). Essential Medical Genetics. 3rd edn. Blackwell Scientific Publications, London.

Dereymaeker, A.M., Fryns, J.P., Haegeman, J., Deroover, J. and Van Den Berghe, H. (1988). A genetic-diagnostic survey in an institutionalized population of 158 mentally retarded patients. The Viaene experience. Clin. Genet. 34: 126-134.

Félix, T.M., Leite, J.C.L., Maluf, S.W. and Coelho, J.C. (1998). A genetic diagnostic survey in a population of 202 mentally retarded institutionalized patients in the south of Brazil. Clin. Genet. 54: 219-223.

Fernandez, R., Méndez, J. and Pásaro, E. (1996). Turner syndrome: a study of chromosomal mosaicism. Hum. Genet. 98: 29-35.

Fong, C. and Brodeur, G.M. (1987). Down's syndrome and leukemia: epidemiology, genetics, cytogenetics and mechanisms of leukemogenesis. Cancer Genet. Cytogenet. 28: 55-76.

Fryns, J.P., Kleczkowska, A., Dereymaker, A., Hoefnagels, M., Heremans, G., Marien, J. and Van Den Berghe, H. (1986). A genetic diagnostic survey in an institutionalized population of 173 severe mentally retarded patients. Clin. Genet. 30: 315-323.

Fryns, J.P., Volcke, P.H., Haspeslagh, M., Beusen, L. and Van Der Berghe, H. (1990). A genetic survey in an institutionalized population of 262 moderately mentally retarded patients: the Borgerstein experience. $J$. Ment. Defic. Res. 34: 29-40.

Gersh, M., Goodart, S.A., Pasztor, L.M., Harris, D.J., Weiss, L. and Overhauser, J. (1995). Evidence for a distinct region causing a cat-like cry in patients with 5p deletions. Am. J. Hum. Genet. 56: 1404-1410.

Giaccardi, A., Sardi, R., Priora, U., Vivalda, M., Domeneghetti, G. and Girone, P. (1991). Trisomia 18 o sindrome di Edwards. Minerva Pediatr. 43: 343-349.

Gustavson, K.H., Hagberg, G. and Sars, K. (1977). Severe mental retardation in a Sweedish county. Epidemiology, gestational age, birth weight and associated CNS handicaps in children born 1959-70. Acta Paediatr. Scand. 66: 373-379.

Hook, E.B. (1977). Exclusion of chromosome mosaicism: tables of $90 \%$, 95\%, and 99\% confidence limits and comments on use. Am. J. Hum. Genet. 29: 94-97.

Iselius, L., Jacobs, P. and Morton, N. (1990). Leukaemia and transient leukaemia in Down syndrome. Hum. Genet. 85: 477-485.

Jorde, L.B., Carey, J.C. and White, R.L. (1996). Genética Humana. Guanabara Koogan, Rio de Janeiro.

Laxova, R., Ridler, M.A.C. and Bower-Bravery, M. (1977). An etiological 
survey of the severely retarded Hertfordshire children who were born between January 1, 1965 and December 31, 1967. Am. J. Med. Genet. 1: 75-86.

Lyons, J.K. (1996). Smith's Recognizable Patterns of Human Malformations. 5th edn. WB Saunders Company, Philadelphia, USA.

Milunsky, A. (1992). Genetic Disorders and the Fetus: Diagnosis, Prevention, and Treatment. 3rd edn. Johns Hopkins University Press, Baltimore.

Moorhead, P.S., Nowell, P.C., Mellman, W.J., Battips, D.M. and Hungerford, D. (1960). Chromosome preparations of leucocytes cultured from human peripheral blood. Exp. Cell Res. 20: 613-616.

Opitz, J.M., Shapiro, S.S. and Uehling, D.T. (1979). Genetic causes and workup of male and female infertility. Postgrad. Med. 65: 157-162.

Organizacion Panamericana De La Salud (OPS) (1984). Prevención y control de las enfermedades genéticas y los defectos congénitos. Publicación Científica No. 460, Washington, D.C.

Pimentel, M.M.G. (1999). Fragile X syndrome (review). Int. J. Mol. Med. 3 : 639-645.
Procter, S.E., Watt, J.L., Lloyd, D.J. and Duffty, P. (1984). Problems of detecting mosaicism in skin. A case of trisomy 8 mosaicism illustrating the advantages of in situ tissue culture. Clin. Genet. 25: 273-277.

Roeleveld, N., Zielhuis, G.A. and Gabreëls, F. (1997). The prevalence of mental retardation: a critical review of recent literature. Dev. Med. Child Neurol. 39: 125-132.

Salamanca, F. and Armendares, S. (1974). C bands in human metaphase chromosomes treated by barium hydroxide. Ann. Genet. 17: 135-136.

Taylor, A.J. (1968). Autosomal trisomy syndromes: a detailed study of 27 cases of Edward's syndrome and 27 cases of Patau's syndrome. $J$. Med. Genet. 5: 227-241.

Thompson, M.W., McInnes, R.R. and Willard, H.F. (1993). Genética Médica. 5th edn. Guanabara Koogan, Rio de Janeiro.

Zool, B., Wolf, J., Lensing-Hebben, D., Pruggmayer, M. and Thorpe, B. (1993). Trisomy 13 (Patau syndrome) with an 11-year survival. Clin. Genet. 43: 46-50.

(Received September 13, 1999) 
